\title{
CYCLOPHOSPHAMIDE HEPATOTOXICITY: THE ROLE OF 4-HYDROXYNONENAL AND CYTOCHROME C OXIDASE AND THE POSSIBLE PROTECTIVE EFFECT OF Ganoderma lucidum EXTRACT
}

\author{
Dina R. S. Gad El-Karim ${ }^{1 *}$, Gamal El-Amrawi² \\ *1Department of Pathology, Clinical Pathology branch, Faculty of Veterinary Medicine, Alexandria \\ University, ${ }^{2}$ Department of Theriogenology, Faculty of Veterinary, Medicine, Alexandria \\ University, 11511, Egypt \\ *Corresponding author, E-mail: Gaddidi@yahoo.com
}

\begin{abstract}
Cyclophosphamide (CPA) is a widely used anti-neoplastic drug, but its usage is associated with several side effects including hepatotoxicity. This study was designed to evaluate the ameliorative effect of Ganoderma lucidium (GL) extract as a natural antioxidant against CPA hepatotoxicity in male Wistar albino rats. Four groups of rats $(n=7)$ were used in this study, Group I: served as a control group, group II: was administrated CPA (5 mg/kg), group III: received GL extract (50 mg/kg), and group IV: received CPA and GL extract at the same doses of groups II and III. All the treatments were orally administrated via gastric intubation for 21 consecutive days. Serum activities of the hepatic enzymes (AST, ALT and GGT) in addition to serum proteinogram were evaluated. Moreover, hepatic oxidant-antioxidant markers (4- hydroxynonenal (4-HNE), GSH, CAT and SOD) besides activity of cytochrome $\mathrm{C}$ oxidase enzyme were detected. Also, histopathological examination of the hepatic sections (H\&E stained) was performed. Serum activity of liver enzymes was elevated, proteinogram was disturbed in CPA-treated animals which accompanied by an increase in hepatic content of 4-HNE, depletion of hepatic antioxidant (GSH, CAT, SOD) and inhibition of hepatic cytochrome $\mathrm{C}$ oxidase activity, also hepatic histopathological disruptions were noticed in this group. All these hepatic disturbances were partially ameliorated upon co-administration of $\mathrm{GL}$ extract with CPA. In conclusion, production of 4- HNE and inhibition of cytochrome $\mathrm{C}$ oxidase enzyme may play a role in occurrence of CPA hepatotoxicity and GL extract may have an ameliorative role against this toxicity.
\end{abstract}

Key words: cyclophosphamide; hepatotoxicity; Ganoderma lucidium; 4-hydroxynonenalon; cytochrome C oxidase

\section{Introduction}

Cyclophosphamide (CPA) is a drug with a wide spectrum of clinical uses especially in the treatment of cancer (lymphoma, acute and chronic leukemia, multiple myeloma) and autoimmune diseases such as rheumatoid arthritis and vasculitis (1). As a chemotherapy, CPA is an alkylating agent depending on formation of phosphoramide mustard (major chemically reactive CPA metabolite) which brings about interstrand cross-links between opposite DNA strands and hampers their replication and tran- 
scription process and this characterizes the clinical activity of CPA (2). Bioconversion of CPA into its metabolites (acrolein and phosphoramide mustard) leads to the formation of high level of reactive oxygen species (ROS), which disturb antioxidant activity inducing CPA-related tissue injuries (3-5).

Oxidative stress (disruption of redox balance) which generates biochemical and physiological disturbances, mediates the injury of normal tissues (as hepatic cells damage and mutagencity) and this is considered the major limitation of CPA usage as an anti-neoplastic drug $(6,7)$. Several studies suggest that antioxidant supplementation can influence the response to chemotherapeutic drugs and attenuate the development of their adverse side effects (8).

Ganoderma lucidum (GL) or Reishi is an oriental fungus which has been recognized as a medicinal mushroom for over 2000 years due to its multiple powerful effects (9). It presents in many commercial forms including dietary supplement, tea or powder which are produced from different mushroom parts as fruits, mycelia or spores (10). GL polysaccharides (GLPS) is one of the major active bio-components of GL which have multiple pharmacological effects, such as antitumor (11), and antioxidant activity (12) in a dose dependent manner (13) through direct free radicals scavenging and ability to increase antioxidant enzymes activity (14), immunomodulation (15). It also has a well proved hepato-protective effect against chemical or immune-related hepatic damage (16-19).

This study was an attempt to prove our hypothesis about the inhibitory effect of 4-hydroxynonenalon and cytochrome $\mathrm{C}$ oxidase enzyme in relation to the occurrence of cyclophosphamide hepato-toxicity and possible attenuating role of Ganoderma lucidium against this toxicity in Wistar albino rats.

\section{Material and methods}

\section{Experimental animal}

Twenty eight adult male Wistar albino rats weighting about 180-200 $\mathrm{g}$ were obtained from Alexandria University Research Institute, Egypt and kept under $12 \mathrm{hr}-12 \mathrm{hr}$ light/dark cy- cles. They were allowed to standard commercial pelleted food with water ad-libitum. The animals were left without any treatment for 10 days for acclimatization. All the experimental procedures of this study were performed according to the instructions of "Care and Use of Laboratory Animals" prepared by Faculty of Veterinary Medicine, Alexandria University, Egypt. The protocol of this study was approved by the Research Ethics Committee of the University.

\section{Drugs}

Commercially available CPA tablets (Endoxan ${ }^{\circledR}$ 50mg, Baxter Oncology $\mathrm{GmbH}$ ) and GL whole fruiting body extract (Standardized Reishi, 376 mg capsules standardized to contain10\% polysaccharides, Nature's Way ${ }^{\circledR}$, USA) were used to accomplish this study. The accurate doses of the drugs were dissolved in saline solution daily and shortly before administration.

\section{Experimental protocol}

The acclimated animals were randomly divided into four equal groups $(n=7)$ and treated as follow: group I (control group): rats received $1 \mathrm{ml}$ saline; group II (GL-treated group): rats received GL extract at a dose of $50 \mathrm{mg} / \mathrm{kg}$ body weight, bw (20); group III (CPA-treated group): rats received CPA at a dose of $5 \mathrm{mg} / \mathrm{kg}$ bw (21); and group IV (CPA+GL-treated group): rats received CPA and GL extract at the same doses of groups II and III. All treatment were orally administrated by gastric intubation for 21 consecutive days.

Twenty four hours after the last administration and under the effect of light ether anesthesia, blood aliquots were collected from retro-orbital venous plexus and then, the animals were dispatched by cervical dislocation to harvest the liver tissue samples. Serum samples were separated by centrifugation of coagulated blood aliquots for $10 \mathrm{~min}$ at $1000 \times \mathrm{g}$ and kept frozen at $-4{ }^{\circ} \mathrm{C}$ for later analysis.

\section{Serum biochemical analysis}

Determination of serum activity of hepatic damage biomarkers enzymes including AST, ALT (22) and GGT (23), in addition to serum 
level of total protein (TP) (24), albumin (25) and globulins (26) were evaluated using commercially available kits (Biosystems, Spain).

\section{Liver homogenate preparation and bio-} chemical assays

The liver of each animal was rinsed with $0.9 \% \mathrm{NaCl}$ and deionized water. The tissues were perfused with phosphate buffer saline (PBS), $\mathrm{pH} 7.4$ containing $0.1 \mathrm{mMethylenedia-}$ minetetraacetate (EDTA) to discard any red blood cell or clots. Small piece of each liver (about $1 \mathrm{~g}$ ) was homogenized in $10 \mathrm{ml}$ ice-cold PBS using Glas-Col ${ }^{\circledR}$ tissue homogenizer and centrifuged at $10,000 \times \mathrm{g}$ for $30 \mathrm{~min}$. Supernatant was separated, filtrated and stored at $-80^{\circ} \mathrm{C}$ in Eppendorf's tubes for detection of catalase enzyme (CAT) activity depending on rate of hydrolysis of hydrogen peroxide (27), superoxide dismutase enzyme (SOD) activity which determined as the rate of inhibition of reaction between superoxide with a WST-1 dye to form a colored product (28) and reduced glutathione (GSH) content which based on reduction of 2nitrobenzoic acid (DTNB) with glutathione (29) using locally available kits (Biodiagnostic, Egypt and Abnova, Taiwan). Protein content of tissue samples was detected spectrophotometerically using Bradford reagent (Sigma-Aldrich, USA) (30).

Detection of hepatic level of 4-HNE and activity of cytochrome C oxidase

According to manufacturer instruction, about $100 \mathrm{mg}$ of hepatic tissues was rinsed with PBS, homogenized in $1 \mathrm{ml}$ of ice-cold PBS and stored overnight at $-20^{\circ} \mathrm{C}$. Two freeze-thaw cycles were done to break the cell membranes; the homogenates were centrifuged for $5 \mathrm{~min}$ at $5000 \mathrm{x}$ g. The supernatant was removed and kept at $4^{\circ} \mathrm{C}$ for assessment of 4-hydroxynonenallevel using specific ELISA kits (Mybiosource, USA) in addition to activity of cytochrome $\mathrm{C}$ oxidase enzyme using specific assay kits (Sigma-Aldrich, USA).

\section{Histopathological examination}

Fixed liver tissues (in $10 \%$ formalin) were sliced into $5 \mu \mathrm{m}$ thick sections after paraffin embedding and stained with hematoxylin and eosin (H\&E) (31) using light microscope.

Semiquantitative grading system for hepatic histopathological alterations

Briefly, five random fields from each animal liver histopathological sections were examined $(\times 100)$, the grade of the detected lesion severity was assessed depending on the percentage of affected area/entire section and recorded as follow: (-): absence of lesion, (+): for mild degree of lesions $(5-25 \%),(++)$ : for moderate lesions degree $(26-50 \%)$ and $(+++)$ : for severe degree of lesions $(\geq 50 \%)$.

\section{Statistical analysis}

The statistical analysis was performed using One-way analysis of variance (ANOVA) to study the effect of different treatment on different studied parameters using analysis SAS system software (32).

\section{Results}

\section{Serum biochemical results}

As shown in Table (1), serum activities of the hepatic enzymes (AST, ALT and GGT) were significantly elevated in CPA-treated animals $(\mathrm{P}<0.05)$ when compared to the control group. Concerning serum proteinogram, none of the treated groups showed any significant changes from control group in serum total protein level $(P<0.05)$, but serum albumin level recorded a significant decrease $(\mathrm{P}<0.05)$ in CPA and CPA+GL-treated group when compared to the control group. While, serum globulins level showed a significant increase ( $\mathrm{P}<$ 0.05) in CPA-treated group which was accompanied by a significant decrease in A/ G ratio when compared to the control group.

In comparison with CPA-treated group, coadministration of GL with CPA significantly decreased the evoked serum hepatic enzymes activity, decreased serum globulins level and significantly reversed $\mathrm{A} / \mathrm{G}$ ratio toward normal control level, but, it did not affect the decreased serum albumin level significantly. Administration of GL extract only to the rats significantly decreased serum activity of different hepatic enzymes (AST, ALT and GGT), $(\mathrm{P}<0.05)$ but, 
it did not have any significant effect on serum proteinogram of these rats as compared to the control group.

\section{Hepatic antioxidant biomarkers}

In comparison with the control group, the liver content of GSH along with hepatic activities of CAT and SOD enzymes recorded a significant decrement $(\mathrm{P}<0.05)$ in the $\mathrm{CPA}$ treated group. Fortunately, these assessed hepatic antioxidant biomarkers were significantly increased in CPA+GL-treated animals as compared to CPA-treated rats. As compared to the control group, GL extract successfully and significantly increased $(\mathrm{P}<0.05)$ these tested antioxidant biomarkers in hepatic tissues of rats when administrated alone (Table 2).

Hepatic level of 4-hydroxynonenal and activity of cytochrome $C$ oxidas enzyme

In CPA-treated group, the hepatic level of 4hydroxynonenal was increased significantly which was coupled with a significant decrease in hepatic activity of cytochrome $\mathrm{C}$ oxidase enzyme $(\mathrm{P}<0.05)$ when compared to the control group. These changes were partially and significantly alleviated when GL extract was administrated with CPA. Compared to the control group, administration of GL extract alone to the rats significantly decreased $(\mathrm{P}<0.05)$ liver content of 4-hydroxynonenal and enhanced the activity of cytochrome $\mathrm{C}$ oxidase enzyme (Table 2).

\section{Histopathological results}

Light microscopy examination of representative histological liver sections of various treated animals groups showed normal and well detailed hepatocytes which were arranged in regular cords around portal vein in area in both of control and GL extract administrated groups (Fig.1). However, CPA-treated group exhibited severe hemorrhage (Fig. 2) with broadening of portal area with mononuclear inflammatory cell and fibroblast besides vacuolar degeneration of the majority of hepatocytes (Fig. 3), but $\mathrm{CPA}+\mathrm{GL}$ extract-treated group showed small focus of necrotic hepatocytes with inflammatory cells infiltration (Fig. 4) with minimal infiltration of these inflammatory cells in portal area (Fig. 5).

Table (3) illustrated the results of histopathological evaluation of the hepatic lesions of different groups using simple semiquantitative scoring system which affirmed the alleviating role of GL extract on the detected hepatic lesions.

\section{Discussion}

Despite of CPA effectiveness in treatment of a wide variety of neoplastic and autoimmune diseases (1), damage or injury of healthy tissues may be the major factor of limited usage of CPA as an anti-neoplastic treatment (33). CPA hepatotoxicity was reported in several studies

Table 1: The effect of different treatments on serum hepatic biomarkers enzymes (AST, ALT and GGT) and serum proteinogram

\begin{tabular}{lcccc}
\hline & Control & GL & CPA & CPA+GL \\
\hline AST (U/L) & $35.20 \pm 2.91 \mathrm{c}$ & $31.80 \pm 3.43 \mathrm{~d}$ & $79.80 \pm 3.85 \mathrm{a}$ & $61.40 \pm 3.61 \mathrm{~b}$ \\
ALT(U/L) & $25.80 \pm 3.12 \mathrm{c}$ & $22.80 \pm 2.63 \mathrm{~d}$ & $69.80 \pm 3.81 \mathrm{a}$ & $40.60 \pm 3.16 \mathrm{~b}$ \\
GGT(U/L) & $22.00 \pm 2.35 \mathrm{c}$ & $19.80 \pm 1.32 \mathrm{~d}$ & $51.60 \pm 2.66 \mathrm{a}$ & $34.20 \pm 2.52 \mathrm{~b}$ \\
TP $(\mathrm{g} / \mathrm{dl})$ & $6.52 \pm 0.19 \mathrm{ab}$ & $6.50 \pm 0.19 \mathrm{ab}$ & $6.88 \pm 0.13 \mathrm{a}$ & $6.02 \pm 0.13 \mathrm{~b}$ \\
Albumin(g/dl) & $4.18 \pm 0.14 \mathrm{a}$ & $4.22 \pm 0.09 \mathrm{a}$ & $2.98 \pm 0.11 \mathrm{~b}$ & $3.56 \pm 0.05 \mathrm{~b}$ \\
Globulins(g/dl) & $2.34 \pm 0.14 \mathrm{~b}$ & $2.28 \pm 0.11 \mathrm{~b}$ & $3.90 \pm 0.14 \mathrm{a}$ & $2.37 \pm 0.08 \mathrm{~b}$ \\
A/G ratio & $1.82 \pm 0.12 \mathrm{a}$ & $1.87 \pm 0.06 \mathrm{a}$ & $0.76 \pm 0.05 \mathrm{c}$ & $1.51 \pm 0.07 \mathrm{~b}$ \\
\hline
\end{tabular}

All the values are expressed as mean \pm SD. Means within the same raw of different litters are significantly different at (P < 0.05). GL: Ganoderma lucidium extract, CPA: Cyclophosphamide, CPA+GL: Cyclophosphamide+ Ganoderma lucidium extract. 
Table 2: The effect of different treatments on hepatic antioxidants content (GSH, CAT and SOD), 4-HNE level and cytochrome $\mathrm{C}$ oxidase activity

\begin{tabular}{lllll}
\hline & \multicolumn{1}{c}{ Control } & \multicolumn{1}{c}{ GL } & \multicolumn{1}{c}{ CPA } & \multicolumn{1}{c}{ CPA+GL } \\
\hline GSH (mmol/mg protein) & $79.00 \pm 3.18 \mathrm{~b}$ & $110.60 \pm 4.45 \mathrm{a}$ & $37.20 \pm 2.80 \mathrm{~d}$ & $55.80 \pm 2.84 \mathrm{c}$ \\
CAT (U/mg protein) & $10.10 \pm 0.87 \mathrm{~b}$ & $17.00 \pm 0.79 \mathrm{a}$ & $3.58 \pm 0.39 \mathrm{~d}$ & $7.40 \pm 0.43 \mathrm{c}$ \\
SOD (U/mg protein) & $9.72 \pm 0.82 \mathrm{~b}$ & $16.04 \pm 0.62 \mathrm{a}$ & $4.02 \pm 0.18 \mathrm{~d}$ & $6.76 \pm 0.40 \mathrm{c}$ \\
4-HNE (pg/mg protein) & $13.90 \pm 1.49 \mathrm{c}$ & $8.10 \pm 0.64 \mathrm{~d}$ & $48.40 \pm 3.08 \mathrm{a}$ & $29.00 \pm 2.93 \mathrm{~b}$ \\
Cytochrome C oxidase (U/mg protein) & $51.20 \pm 3.34 \mathrm{~b}$ & $66.40 \pm 3.04 \mathrm{a}$ & $25.80 \pm 2.22 \mathrm{~d}$ & $35.40 \pm 2.80 \mathrm{c}$ \\
\hline
\end{tabular}

All the values are expressed as mean \pm SD. Means within the same raw of different litters are significantly different at $(\mathrm{P}<0.05)$.

Table 3: The score of detected hepatic lesions in male Wistar albino rats of different experimental groups

\begin{tabular}{lcccccccc}
\hline \multicolumn{1}{c}{ Scored liver lesions } & \multicolumn{7}{c}{ Incidence $^{1}$ and Severity } \\
& $\begin{array}{c}\text { Absent histopathological lesions } \\
\text { CPA-treated rats }\end{array}$ & $\begin{array}{c}\text { Mild } \\
(-)\end{array}$ & $\begin{array}{c}\text { Moderate } \\
(++)\end{array}$ & $\begin{array}{c}\text { Severe } \\
(+++)\end{array}$ & $\begin{array}{c}\text { Absent } \\
(-)\end{array}$ & $\begin{array}{c}\text { Mild } \\
(+)\end{array}$ & $\begin{array}{c}\text { Moderate } \\
(++)\end{array}$ & $\begin{array}{c}\text { Severe } \\
(+++)\end{array}$ \\
\hline 1-Congestion of blood vessels & & 2 & 3 & 2 & 0 & 4 & 3 & 0 \\
2-Hepatocytes vacuolar degeneration & 0 & 0 & 4 & 3 & 2 & 2 & 2 & 1 \\
3-Portal Inflammatory cells infiltration & 0 & 1 & 4 & 2 & 1 & 3 & 3 & 0 \\
4-Hepatocellular necrosis & 0 & 2 & 3 & 2 & 2 & 2 & 3 & 0 \\
5-Hyperplasia of biliary epithelium & 0 & 3 & 2 & 2 & 0 & 5 & 2 & 0 \\
6-Hemorrhage & 0 & 4 & 2 & 1 & 7 & 0 & 0 & 0 \\
\hline
\end{tabular}

${ }^{1}$ Number of rats with lesions per total examined (7 rats).

${ }^{2}$ Severity of lesions was graded by estimating the percentage area affected in the entire section.

(34-37) as the liver is the primary site for microsomal activation of this drug (38). The prime cause may be reactive oxygen species (ROS) generation including hydrogen peroxide and superoxide anion during CPA metabolism which in role exhaust anti-oxidant mechanisms of liver $(3,39)$. This action may be exaggerated by CPA reactive metabolite (Acrolin) which can react with hepatic GSH causing its depletion (40) which collectively increase susceptibility of lipid peroxidation and hepatic tissues injury (41).

The previous mechanisms of CPA-induced hepatotoxicity may explain the significant increase in serum hepatic enzymes activity (AST, ALT and GGT) of CPA-treated animals which in a concomitant with decreased activity of CAT and SOD enzymes in addition to depletion of GSH in hepatic tissues of the same group may represent a sufficient indicators for the oc- currence of oxidative injury of hepatocytes consistently with several previously recorded findings $(20,36,42)$. Several studies have reported that GL extract is a good free radical scavenger $(13,43,44)$, so treatment with GL rendered some protection against CPA-hepatotoxicity which was evidenced by a significant decrease in serum activity of AST, ALT and GGT which accompanied by a significant increase in hepatic tissues content of GSH and activity of antioxidant enzymes (CAT and SOD) in CPA+GL-treated group when compared to the CPA-treated group. Hepatoprotective effect of GL against oxidative damage was previously detected and proved (18). Albumin is one of plasma proteins which is synthesized by liver so, determination of its levels is considered one of best indicators to evaluate hepatic function efficacy (45) and this may demonstrate its decrease in both of CPA and CPA+GL-treated groups which may be attributed to hepatotoxic 


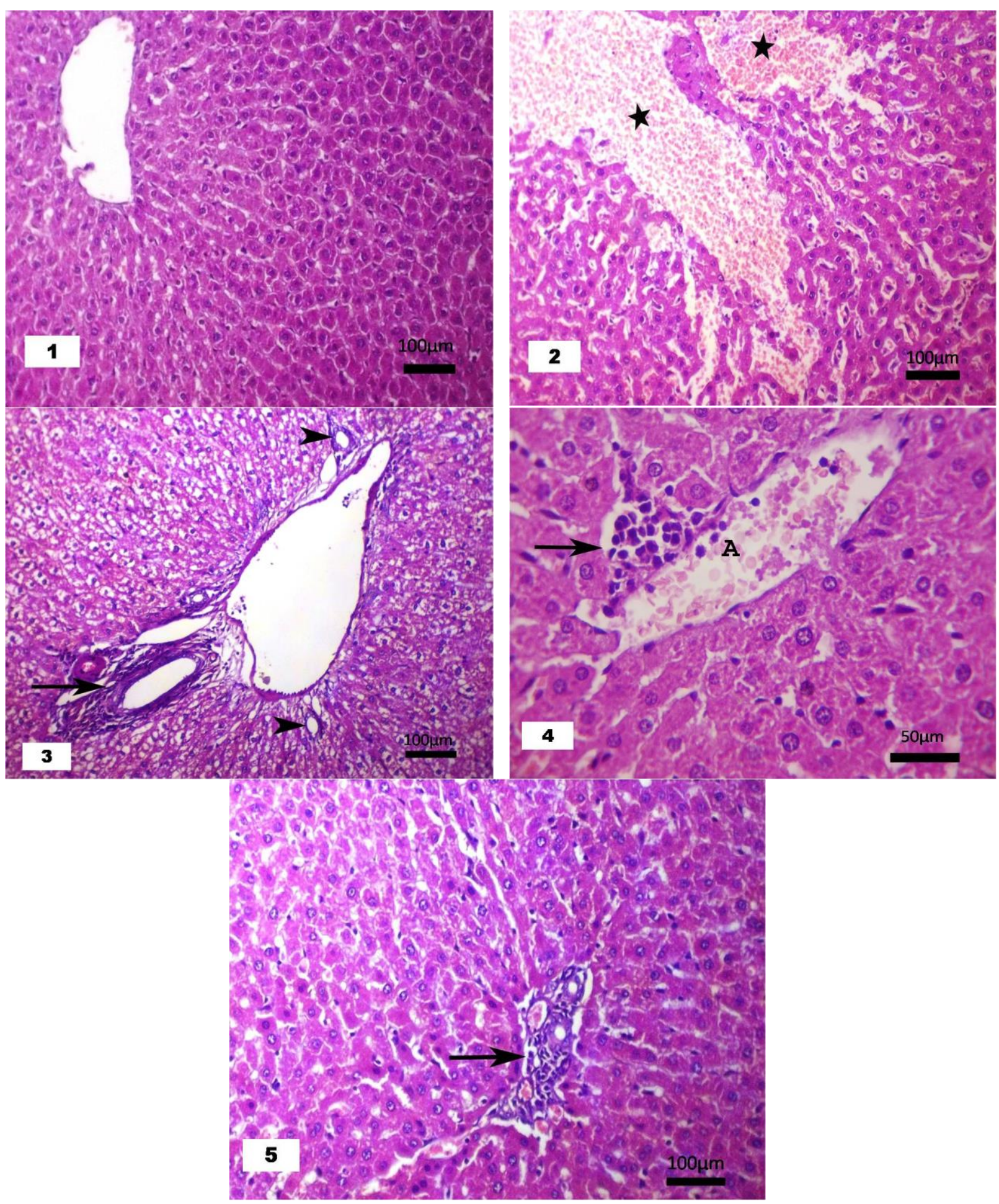

Figure 1: (1) Control group, a section in the liver of a rat showing normal hepatocytes (H\&E, X200). (2) CPA-treated group, a section in the liver of a rat showing focal hemorrhage (stars, H\&E, X200). (3) CPA-treated group, a section in the liver of a rat showing thickening of portal area with mononuclear cells infiltrate and fibrosis (arrow) and hyperplasia of biliary epithelium (arrow heads) besides hydropic degeneration or vacuolation of most of hepatocytes (H\&E, X200). (4) CPA+GL-treated group, a section in the liver of a rat showing congested blood vessel (A) and necrosis hepatocytes with inflammatory cells infiltrate (arrow, H\&E, X400), (5) CPA+GL-treated group, a section in the liver of a rat showing mononuclear inflammatory cells in the portal area (arrow, H\&E, X200) 
impact of CPA, while hyperglobulinemia of hepatocellular disorders, appearing as an inflammatory response to liver injury due to the probable increase in production alpha and beta globulins by liver and/or immune- globulins by plasma cells $(45,46)$. The previous explanation may clarify the reasons for hypoalbuminemia and hyperglobulinemia which significantly decreased $\mathrm{A} / \mathrm{G}$ ratio of $\mathrm{CPA}$-treated animals which could be attributed to CPA hepatotoxic effects. The treatment with GL significantly ameliorated these changes in proteinogram and clearly lessens the decrease in $\mathrm{A} / \mathrm{G}$ ratio caused by CPA treatment, thereby GL may exhibit a considerable suppressive effect on hepatic inflammatory reactions caused by CPA, this ameliorative effect of GL on hepatic inflammatory state was concluded formerly (18).

4-hydroxynonenal is the major lipid peroxidation product which is produced in the tissues as a result of cellular exposure to oxidative stress (47). It has a suppressive effect on cytochrome C oxidase enzyme activity $(48,49)$ which is the key enzyme of aerobic cell respiration that contributes to the formation of ATP (essential energy molecules for cell livability and viability), so deficiency of this enzyme represent a risk for the living cells (50). The proved oxidative stress caused by CPA administration may demonstrate the increment in hepatic tissues level of 4-hydroxynonenalwhich in turn may be the cause for the decrement in these tissues activity of cytochrome $\mathrm{C}$ oxidase enzyme. Another explanation for inhibition of hepatic cytochrome $\mathrm{C}$ oxidase enzyme in CPAtreated rats may be the great susceptibility of its mRNA as well as protein to oxidative damage (51).

The later changes were alleviated by the dosage of powerful antioxidant GL extract to the rats of the CPA+GL group. Hence, the antioxidant activity of GL was reflected on the effects of its supplementation as a sole treatment to the rats of GL-treated group, as it successfully boosted the hepatic antioxidant biomarkers (GSH, CAT, SOD), which in role, decreased hepatocytes destruction and leakage of hepatic enzymes to the blood and finally decreased hepatic level of 4-HNE and enhanced the activity of cytochrome $\mathrm{C}$ oxidase enzyme as compared to control group.

In this study, histopathological examination of liver, affirmed that CPA can cause damage to the liver which was evidenced by presence of several different hepatic lesions, which might be caused by cellular damaging potential of CPA metabolites in relation to generation of ROS in agreement with the current studies on CPA-induced hepatotoxicity $(38,42,52)$. These histopathological changes correlated strongly with the altered serum enzymes activity and hepatic antioxidants depletion of CPA-treated group. Semiquantiative evaluation of hepatic lesion confirmed the biochemical results which illuminated that the treatment with GL extract effectively ameliorated the abnormal hepatic histopathological lesions caused by CPA, and this may be attributed to its powerful antioxidant ability in prevention of ROS membrane damage $(12,16,18)$.

\section{Conclusion}

Our results reported the role of 4-hydroxynonenal production and inhibition of cytochrome $\mathrm{C}$ oxidase enzyme in CPA-induced hepatic damage. In addition, it clarified and supported that the treatment with GL extract can reduce oxidative hepato-cyto damage caused by treatment with cyclophosphamide due to its powerful antioxidant effect, so it can be used during treatment with this anti-cancer drug to minimize its deleterious effects on the liver.

\section{Conflict of interest}

The authors declare that she has no conflict of interest.

\section{References}

1. Dollery C. Cyclophosphamide. In: Therapeutic Drugs. Edinburgh: Churchill Livingstone1999; 349-53.

2. Paolo AD, Danesi R, Tacca MD. Pharmacogenetics of neoplastic disease: New Trends. Pharmacol Res 2004; 49: 331-42.

3. Stankiewicz A, Skrzydlewska E, Makiela M. Effects of amifostine on liver oxidative stress caused by cyclophosphamide administration to rats. Drug Metabol Drug Interact 2002; 19: 67-82. 
4. Haque R, Bin-Hafeez B, Parvez S, Pandey S. Aqueous extract of walnut (Juglans regia L.) protects mice against cyclophosphmide induced biochemical toxicity. Human Exp Toxicol 2003; 22:473-80.

5. Bhatia K, Ahmad F, Rashid H, Raisuddin S. Protective effect of S-allylcysteine against cyclophosphamide-induced bladder hemorrhagic cystitis in mice. Food Chem Toxicol 2008; 46(11):336874.

6. Chakraborty P, Hossain U, Murmu N, Das JK, Pal S, Bhattacharya S. Modulation of cyclophosphamide-induced cellular toxicity by diphenylmethyl selenocyanate in vivo, an enzymatic study. J Cancer Mol 2009; 4(6): 183-9.

7. Mousa NK, Muhsin EA, Sabbar SS, Ishrak A. Ahmed IA. Liver histopathological of purification cinnamic acid activity against endoxan in mice. $\mathbf{J}$ Gen Enviro Reso Cons 2014; 2(1): 22-9.

8. Weijl NI, Cleton FJ, Osanto S. Free radicals and antioxidants in chemotherapy-induced toxicity. Cancer Treat Rev 1997; 23 (4): 209-40.

9. Wasser SP. Reishi or Lingzhi (Ganoderma lucidium). Encyclopedia of dietary supplements 2005; 1: 603-22.

10. Watchel-Galore S, Yuen J, Buswell JA. Ganoderma Lucidium (Lingzhi or Reishi): a Medicinal Mushroom. In: Benzie IFF, Watchel-Galore S, editors. Herbal Medicine: Bimolecular and Clinical Aspects. $2^{\text {nd }}$ edition. Boca Raton (FL): CRC Press/Taylor \&Francis; 2011. Chapter 9.

11. Lin ZB, Zhang H. Anti-tumor and immunoregulatory activities of Ganoderma lucidum and its possible mechanisms. Acta Pharmacol Sin; 2004, 25 (11): 1387-95.

12. Lee JM, Kwon H, Jeong H, Lee JW, Lee SY, Baek SJ, Surh YJ. Inhibition of Lipid Peroxidation and Oxidative DNA Damage by Ganoderma lucidum. Phytother Res 2001; 15:245-9.

13. Zhu MQ, Chang LK, Wong FS, Li RC. Triterpene antioxidants from Ganoderma lucidum. Phytotherapy Res1999; 13(6): 529-31.

14. Kao CH, Jesuthasan AC, Bishop KS, Glucina MP, Ferguson LR. Anti-cancer activities of Ganoderma lucidum: active ingredients and pathways. Fun Foods Health Dis 2013; 3(2):48-65.

15. Lin Z. Cellular and Molecular Mechanisms of Immuno-modulation by Ganoderma lucidum. J Pharmacol Sci 2005; 99: 144-53.

16. Kim KC, Kim IG. Ganoderma lucidum extract protects DNA from strand breakage caused by hydroxyl radical and UV irradiation. Int J Mol Med 1999; 4(3): 273-7.
17. Zhang GL, Wang YH, Ni W, Teng HL, Lin ZB, Lin ZB. Hepatoprotective role of Ganoderma Lucidium polysaccharide against BCG induced immune liver injury in mice. World J Gastroenterol 2002; 8 (4): 728-33.

18. Lin WC, Lin WL. Ameliorative effect of Ganoderma lucidum on carbon tetrachloride-induced liver fibrosis in rats. World J Gastroenterol 2006; 12(2):265-70.

19. Wang X, Zhao X, Li D, Lou YQ, Lin ZB, Zhang GL. Effects of Ganoderma lucidum Polysaccharide on CYP2E1, CYP1A2 and CYP3A Activities in BCG-Immune Hepatic Injury in Rats. Biol. Pharm. Bull 2007; 30 (9): 1702-6.

20. Shieh YH, Liu CF, Huang YK, Yang JY, $\mathrm{Wu}$ L, Lin CH, Lin SC. Evaluation of the Hepatic and Renal-protective Effects of Ganoderma lucidum in Mice. Am Chin Med 2001; 29(3): 501-7.

21. Ghosh S, Ghosh D, Chattopadhyay S, Depnath J. Effect of Ascorbic Acid Supplementation on Liver and Kidney Toxicity in Cyclophosphamide Treated Female Albino Rats. The J toxicol Sci 1999; 24(3): 141-4.

22. Reitman S, Frankel S. A coloremetric method for determination of oxaloacetic transaminase and serum glutamic pyruvic transaminase. Am. J. Clin Pathol 1957; 28: 56-63.

23. Szasz ZG. A kinetic photometric method for serum gamma glutamyltranspeptidase. Clin. Chem 1969; 15:124-36.

24. Doumas BT, Bayso DD, Caster RJ, Leters $\mathrm{T}$, Schaffer R. Determination of serum total protein. Clin. Chem 1981; 27: 1642.

25. Drupt F. Dosage del albumin serque part vert de bromocresol. Pharma. Biol 1974; 111: 77.

26. Watson D. Albumin and "total globulin" fraction of blood. In: Advances in Clinical Chemistry. Academic Press Inc. 1965; 8: 238-49.

27. Aebi H. Catalase in vitro. Methods Enzymol 1984; 105: 121-6.

28. Ukeda H, Maeda S, Ishii T, Sawamura M. Spectrophotometric assay for superoxide dismutase based on tetrazolium salt 3' $\{1-[($ phenylamino $)$-carbonyl]-3,4- tetrazolium \}-bis(4-methoxy-6-nitro) benzenesulfonic acid hydrate reduction by xanthine-xanthine oxidase. Anal Biochem1997; 251: 206-9.

29. Beutler E, Duron O, Kelly MB. Reduced glutathione determination. J Lab Clin Med 1963; 61:882.

30. Bradford MM. A rapid and sensitive method for the quantitation of microgram quantities of protein utilizing the principle of protein-dye binding, Anal Biochem1976; 72 (1-2): 248-54. 
31. Bancroft JD, Stevens A. Theory and Practice of Histological Technique. 4th ed. Churchil livingestone; 1996.

32. SAS. Statistical analysis system. SAS User's Guide, SAS incorp Inst 2004.

33. Patel JM. Stimulation of cyclophosphamideinduced pulmonary microsomal lipid peroxidation by oxygen. Toxicology 1987; 45: 79-91.

34. McDonald GB, Slattery GH, Bouvier ME, Ren S, Batchelder AL et al. Cyclophosphamide metabolism, liver toxicity, and mortality following hematopoietic stem cell transplantation. Blood $\mathbf{J}$ 2003;101: 2043-8.

35. Sheeja K, Kuttan. Ameliorating Effects of Andrographis Paniculata Extract Against Cyclophosphamide-Induced Toxicity in Mice. Asia Pac Can Prev 2006; 7: 609-14.

36. Alenzi FQ, El-Bolkiny YE, Salem ML. Protective effects of Nigella sativa oil and thymoquinone against toxicity induced by the anticancer drug cyclophosphamide. BRIT J BIOMED SCI 2010; 67 (1):20-8.

37. Jain R, Jain SK. Effect of Buchanania lanzan Spreng bark extract on cyclophosphamide induced genotoxicity and oxidative stress in mice. Asia Paci J Trop Med 2012; 187-91.

38. Shokrzadeh M, Ahmadi A, Naghshvar F, Chabra A, Jafarinejhad M. Prophylactic Efficacy of Melatonin on Cyclophosphamide-Induced Liver Toxicity in Mice. BioMed Res Int 2014; Article ID 470425 .

39. Bhattacharya A, Lawence RA, Krishnan A, Zaman K, Sun D, Fernandes G. Effect of dietary n3 and n-6 oils with and without food restriction on activity of antioxidant enzymes and lipid peroxidation in livers of cyclophosphamide treated autoimmune-prone NZB/W female mice . J Am Coll Nutr 2003; 22: 388-99.

40. Kehrer JP, Biswal SS. The molecular effects of acrolein. Toxicol Sci 2000; 57:6-15.

41. Werts ED, Gould MN. Relationships between cellular superoxide dismutase and susceptibility to chemically induced cancer in the rat mammary gland. Carcinogen1986; 7:1197-201.

42. Shokrzadeh M, Chabra A, Ahmadi A , Naghshvar F, Habibi E, Salehi F, Assadpour S.
Hepatoprotective Eff ects of Zataria Multifl ora Ethanolic Extract on Liver Toxicity Induced by Cyclophosphamide in Mice. Drug Res 2014; 64: 1-7.

43. Kim DH, Shim SB, Kim NJ, Jang LS. Beta Glucoronidase Inhibitory Activity and Hepatoprotective Effect of Ganoderma Lucidium. Biol Pharm Bull 1999; 22(2): 162-4.

44. Zhong D, Wang H, Liu M, Li X, Huang M, Zhou $\mathrm{H}$ et al. Ganoderma lucidum polysaccharide peptide prevents renal ischemia reperfusion injury via counteracting oxidative stress. Sci Rep 2015; 5:16910.

45. Latimer KS, Mahaffey EA, Prasse KW. Plasma Protein. In: Veterinary Laboratory Medicine, Clinical Pathology. 4th Ed., Iwoa State Press; 2003. p. 162-71.

46. Vandenberghe J. Hepatotoxicology: Mechanisms of liver toxicity and methodological aspects. In: Niesink RJM, De Vries J, Hollinger MA. Toxicology: Principle and Applications. New York: CRC Press, 1996; 703-23.

47. Chen JJ, Schenker S, Henderson GI. 4-Hydroxynonenal Levels Are Enhanced in Fetal Liver Mitochondria by In Utero Ethanol Exposure. HEPATOL 1997; 25(1):142-7.

48. Chen J, Robinson NC, Schenker S, Frosto T, George I. Henderson GI. Formation of 4-Hydroxynonenal Adducts With Cytochrome c Oxidase in Rats Following Short-Term Ethanol Intake. HEPATOL 1999; 29 (6): 1792-8.

49. Srinivasan S, Avadhani NG. Cytochrome c Oxidase dysfunction in oxidative stress. Free Rad Biol Med 2012; 53(6): 1252-63.

50. Wikstrom M. Cytochrome C Oxidase. eLS. 2001. https://doi.org/10.1002/9780470 015902.a00 00649.pub2.

51. Sohal RS, Toroser D, Bre'ge're C, Mockett $\mathrm{RJ}$ and Orr WC. Age-related decrease in expression of mitochondrial DNA encoded subunits of cytochrome c oxidase in Drosophila melanogaster. Mech Ageing Dev 2008; 129: 558-61.

52. Senthilkumar S ,Devaki T, Manohar BM, Babu MS. Effect of squalene on cyclophosphamide-induced toxicity . Clin Chim Acta 2006; 364: 335-42. 